\title{
Przegląd metod wizualizacji wiarygodności dawnych map pod względem dokładności geometrycznej na przykładzie mapy Śląska Cieszyńskiego
}

\author{
Maria Kuźma \\ https://orcid.org/0000-0002-6166-480X \\ Katedra Geomatyki i Kartografii, Wydział Nauk o Ziemi i Gospodarki Przestrzennej, Uniwersytet Marii \\ Curie-Skłodowskiej w Lublinie
}

Zarys treści: W artykule dokonano przeglądu sposobów wizualizacji wyników oceny wiarygodności dawnych map pod kątem możliwości ich zautomatyzowania. Badanie wykonano na przykładzie mapy Le Duche de Cieszyn (Teschen) Silesie, z zasobu pozostałego po konferencji pokojowej kończącej pierwszą wojnę światową. Oceniono formy prezentacji wyników, oferowane przez twórców aplikacji MapAnalyst, QGIS oraz ArcMap i ArcScene z pakietu ArcGIS. Otrzymane obrazy oceniono pod kątem możliwości interpretacyjnych, tj. wyobrażenia sobie na ich podstawie stopnia deformacji powierzchni i odległości na mapie przez odbiorców niekorzystających na co dzień z kartograficznych metod prezentacji. Wskazano siatkę zniekształceń i wizualizację 3D sumy błędów odległości jako najbardziej użyteczne.

Słowa kluczowe: kartometryczność dawnych map, konferencja pokojowa w Paryżu 1919-1920, HGIS, wizualizacja zniekształceń map

\section{Wstęp}

Dawne mapy w badaniach historycznych są cennym źródłem informacji nie tylko do odtwarzania dziedzictwa kulturowego, śledzenia ewolucji elementów krajobrazu naturalnego lub infrastruktury drogowej, ale także analizy technik sporządzania map i stanu wiedzy geograficznej z czasu ich powstania ${ }^{1}$. Wykorzystując dawne mapy w badaniach historycznych należy upewnić się, że są one wiarygodne pod względem topograficznym, chronometrycznym

B. Jenny, L. Hurni, Studying cartographic heritage. Analysis and visualization of geometric distortions, „Computers \& Graphics”, 35 (2), 2011, s. 402-411.
Abstract: The article reviews methods of visualizing the reliability assessment results of old maps in terms of the possibility of automating them. The study was based on the example of the map Le Duche de Cieszyn (Teschen) Silesie, from the collection remaining after the Peace Conference ending World War I. The forms of presentation of the results offered by the developers of MapAnalyst, QGIS, ArcMap, and ArcScene applications from the ArcGIS package are evaluated. The obtained images were viewed in terms of interpretative possibilities, i.e. imagining on their basis the degree of surface deformation and distance on the map by recipients who do not use cartographic presentation methods daily. The distortion grid and $3 \mathrm{D}$ visualization of the sum of distance errors were indicated as the most useful.

Keywords: accuracy of old maps, Paris Peace Conference 1919-1920, HGIS, visualization of map distortions

i geometrycznym ${ }^{2}$. Wykonane zgodnie z zasadami redakcji kartograficznej są niepodważalnym i wieloaspektowym źródłem informacji o przeszłości obszaru, uzupełniającym wiedzę o jego dziedzictwie przyrodniczym i kulturowym ${ }^{3}$. Interesujące wnioski przedstawiają również badacze analizujący dawne mapy jako jedną z form komunikacji społecznej, wykorzystywaną

\footnotetext{
${ }^{2}$ M.J. Blakemore, J.B. Harley, Concepts in the history of cartography. Are view and perspective, „Cartographica”, 17, 1980, s. 1-120.

${ }^{3}$ B. Konopska, Funkcje map przemystu Polski w atlasach wydanych w okresie PRL a sposób prezentacii danych, w: Z dziejów przemystu po 1945 roku. Wrocławskie Spotkania z Historią Gospodarczą - Spotkanie VII, red. E. Kościk, R. Klementowski, Wrocław 2012, s. 21-32.
} 
w działalności politycznej i propagandowej. Wielu dowodów na wykorzystanie kartograficznych metod prezentacji do przekazywania określonych idei lub wyselekcjonowanych informacji konkretnym grupom społecznym dostarczyli m.in. Denis Wood ${ }^{4}$, Mark Monmonier ${ }^{5}$, Jérôme Monnet $^{6}$ i na gruncie polskim Beata Konopska ${ }^{7}$ czy Dorota Borowicz ${ }^{8}$. Mapy częstokroć także rejestrują problemy geopolityczne i spory dotyczące granic państwowych. W XX w. po obydwu wojnach światowych były wykorzystywane do zaprojektowania nowego podziału Europy ${ }^{9}$.

Spuścizna kartograficzna po konferencji pokojowej kończącej pierwszą wojnę światową to dziesiątki interesujących map i źródeł pisanych, na podstawie których te mapy opracowano lub którym one towarzyszyły ${ }^{10}$. Zasób kartograficzny zgromadzony w ramach projektu „Kształtowanie granic niepodległej Polski w świetle dokumentów kartograficznych" ${ }^{11} \mathrm{z}$ jednej strony pozwolił wprowadzić wiele uzupełnień odnoszących się do ogólnych tez przyjętych w literaturze przedmiotu na temat roli map w tym wydarzeniu, $\mathrm{z}$ drugiej sprowokowat wiele nowych pytań. Jedno $\mathrm{z}$ nich wiąże się $\mathrm{z}$ badaniem

\footnotetext{
${ }^{4}$ D. Wood, The Power of Maps, New York 1992.

${ }^{5}$ M. Monmonier, How to Lie with Maps, Chicago 1996.

${ }^{6}$ J. Monnet, The Symbolism of Place. A Geography of Relationships between Space, Power and Identity, „Cybergeo. European Journal of Geography. Political, Cultural and Cognitive Geography", 562, 2011 (http://cybergeo. revues.org/24747, dostęp: 14 października 2021).

${ }^{7}$ B. Konopska, Wptyw aparatu władzy w latach 1944-1989 na polskie publikacje kartograficzne do użytku powszechnego, Warszawa 2012.

${ }^{8}$ D. Borowicz, Dawne mapy przedmiotem manipulacji i narzędziem propagandy, ,ZZ Dziejów Kartografii”, 21, 2017, s. 183-202.

${ }^{9}$ L. Szaniawska, Obraz granic państwowych Polski w latach 1945-1958 na mapach towarzyszących bilateralnym umowom państwowym, „Z Dziejów Kartografii", 23, 2020, s. 137-162; D. Przybytek, Kartograficzna wizja odradzającej się Polski w latach 1916-1921 izmiana jej granic po 1945 roku, „Z Dziejów Kartografii”, 23, 2020, s. 121-136.

${ }^{10}$ B. Konopska, The Cartographic Materials Auxiliary in the Determination of the Borders of Poland during the Paris Peace Conference (1919-1920) in the Light of Archival Records, „Polish Cartographical Review”, 48 (2), 2016, s. 67-75.

${ }^{11}$ „Ksztattowanie granic niepodległej Polski w świetle dokumentów kartograficznych", projekt finansowany w ramach programu MNiSW pod nazwą „Szlakami Polski Niepodległej” w latach 2018-2023, nr projektu 01SPN17003218.
}

kartometryczności map. Interesujące jest bowiem, czy mapy, którymi dyplomaci posługiwali się podczas projektowania przebiegu nowych granic państwowych, kiedy lobbowali, kiedy podejmowali decyzje o nowym podziale Europy, odwzorowywały poprawnie powierzchnię i właściwie lokalizowały miejscowości. Pytanie to było o tyle zasadne, że odnaleziony materiał jest bardzo różnorodny pod względem poziomu opracowania kartograficznego ${ }^{12}$. Wiele map dotyczących szczegółowych zagadnień używanych było $\mathrm{w}$ formie drukowanych pierworysów, z ręcznie uzupełnianą treścią. Autorka, badając kartometryczność obiektów z tego zasobu, zwłaszcza tych pozbawionych elementów matematycznych, opracowała autorskie narzędzie przyspieszające ten żmudny proces badawczy poprzez obliczanie skali ogólnej. Wyniki tej pracy opublikowane zostały na łamach „Polish Cartographical Review”"13. Procedurę badania kartometryczności można zakończyć zestawieniem wyników w formie tabelarycznej, które da się fakultatywnie zwizualizować.

Tabela wyników jest podstawą do wykonania ostatniego działania, tj. wizualizacji. Możliwości automatowej wizualizacji, jakie dają programy GIS, wywołują kolejne pytanie: która $\mathrm{z}$ form prezentacji błędów będzie najbardziej przekonująca i zrozumiała dla zespołu opracowującego merytorycznie tę spuściznę oraz innych osób, niekorzystających na co dzień z kartograficznych metod prezentacji. W artykule dokonano przeglądu sposobów wizualizacji wyników badania kartometryczności, dostępnych w narzędziach GIS i wytypowano te

\footnotetext{
${ }^{12}$ B. Konopska, M. Barwiński, Przegląd odnalezionych źródet kartograficznych i tekstowych. Część pierwsza - Mapy Polski, 2019 (https://doi.org/10.13140/ RG.2.2.17544.55041); B. Konopska, M. Barwiński, Przegląd odnalezionych źródeł kartograficznych i tekstowych. Czesść czwarta - Granica zachodnia i pótnocna, 2021 (https://doi.org/10.13140/RG.2.2.12728.47366); B. Konopska, M. Barwiński, Przegląd odnalezionych źródet kartograficznych i tekstowych. Część trzecia - Mapy Śląska Cieszyńskiego, Orawy i Spisza, 2021 (https://doi.org/10.13140/RG.2.2.33442.76485).

${ }^{13} \mathrm{M}$. Kuźma, The use of GIS Tools in the Automation of Examining the Cartometry of Old Maps, „Polish Cartographical Review”, 52 (4), 2020, s. 152-161.
} 


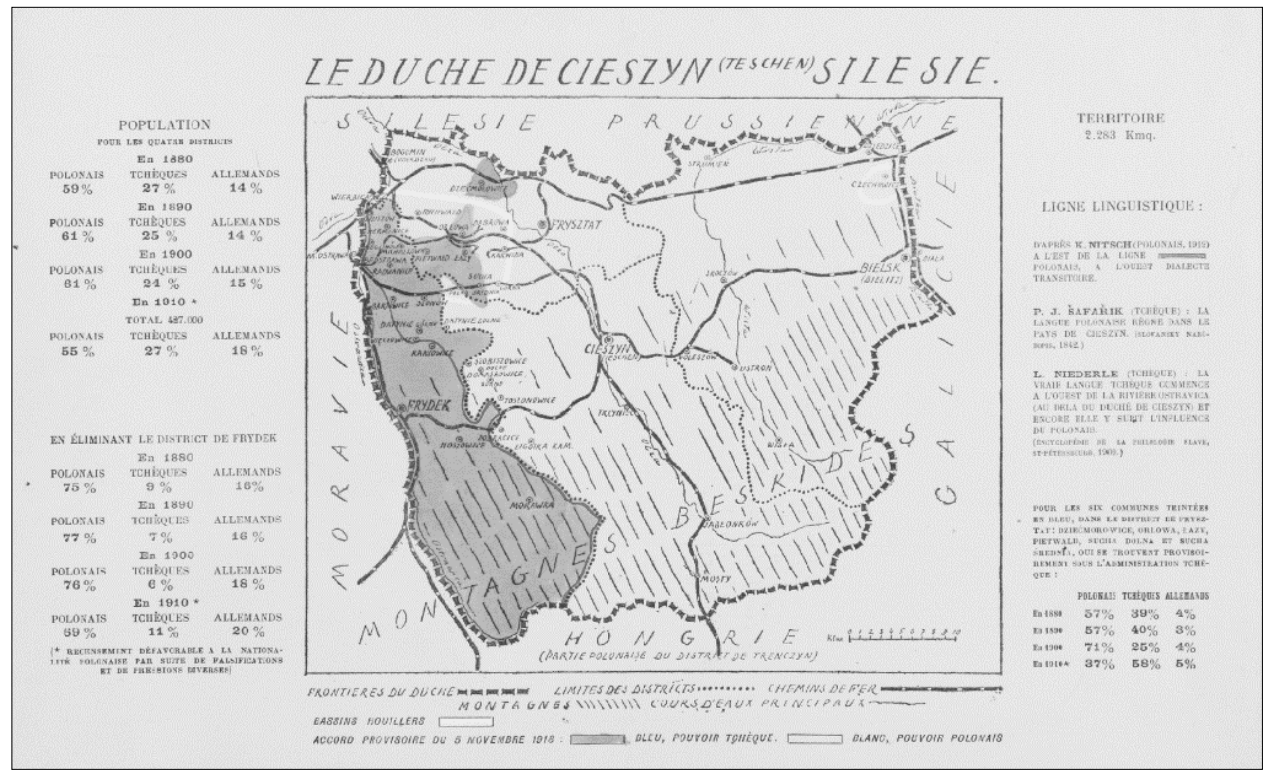

Ryc. 1. Mapa "Le Duche de Cieszyn (Teschen) Silesie”.

Żródto: Archiwum Akt Nowych, CIII - zbiór kartograficzny mapy XX wiek, sygn. 2354

najbardziej czytelne i jednoznaczne formy przedstawienia błędów badanych map, tj. charakteryzujących się niskim wskaźnikiem deformacji.

\section{Źródło kartograficzne}

Jako materiał badawczy wykorzystano mapę drukowaną Le Duche de Cieszyn (Teschen) Silesie ${ }^{14}$ (ryc. 1), ze względu na jej dużą popularność w zebranym zasobie. Jej egzemplarze występują w zespołach archiwalnych zachowanych po konferencji paryskiej, w spuściznach prywatnych oraz, wiele na to wskazuje, była ona podstawą do opracowania innych map, zachowanych w formie rękopiśmiennej, a dopiski na różnych egzemplarzach dowodzą jej użytkowania w czasie, kiedy ważyły się losy tego regionu.

Opracowanie mapy należy wiązać z negocjacjami o przynależność państwową Śląska Cieszyńskiego, który podzielono na podstawie kryterium językowego

\footnotetext{
${ }^{14}$ Archiwum Akt Nowych, zespół Clll - zbiór kartograficzny mapy XX wiek, sygn. 2354
}

w listopadzie 1918 r., oddając pod polską administrację obszar zamieszkały w większości przez ludność polskojęzyczną, a przy tym bogaty w kopalnie węgla kamiennego i zakłady przemysłowe. Taki podział nie znalazł przychylności Czechosłowacji, która wysunęła kryterium historyczne i oczekiwała przydzielenia jej całego obszaru Księstwa Cieszyńskiego. Języki (polski, francuski, angielski), w których opracowano mapę, wyraźnie wskazują na jej cel konferencyjny.

Mapa przedstawia obszar Księstwa Cieszyńskiego - granice powiatów, główne miasta i linie kolejowe, miejsca występowania węgla kamiennego i granicę obszarów pod tymczasowymi administracjami polską i czeską. Na marginesach arkusza umieszczono dodatkowe informacje dotyczące struktury narodowościowej tego obszaru według wyników spisów ludności z lat 1880, 1890, 1900, 1910. Na mapie brak nazwiska autora mapy, wydawcy oraz miejsca i roku wydania.

Mapa Le Duche de Cieszyn (Teschen) Silesie z dodatkowymi informacjami 
statystycznymi była dołączana do różnych dokumentów. Omawiany egzemplarz był załącznikiem do memoriału odnoszącego się do granicy między Polską a Czechosłowacją na Śląsku Cieszyńskim, Orawie i Spiszu, przygotowanego przez delegację polską na konferencję pokojową w Paryżu w $1919 \mathrm{r}$.

$\mathrm{Na}$ prawym marginesie mapy zamieszczona jest informacja o powierzchni przedstawionego terenu, która wynosi $2283 \mathrm{~km}^{2}$, natomiast powierzchnia Księstwa Cieszyńskiego obliczona w ArcMap dla Le Duche De Cieszyn wynosi $2336 \mathrm{~km}^{2}$. Tego rzędu nieścisłości przy skali przeglądowej nie stanowią istotnego błędu.

\section{Zastosowane oprogramowanie i jego możliwości automatowej wizualizacji}

W celu przebadania kartometryczności mapy ze spuścizny kartograficznej po konferencji paryskiej wykorzystano aplikację MapAnalyst (www.MapAnalyst.org), opracowaną przez Bernharda Jenny'ego w 2005 r. ${ }^{15}$, oraz programy ArcMap i ArcScene z pakietu ArcGIS.

Przy pomocy aplikacji MapAnalyst skonstruowano siatkę zniekształceń i dokonano oceny ogólnej skali mapy. Wykonano także próby konstrukcji izolinii zmienności skali. Jednak zrezygnowano z owej formy wizualizacji dokonanej bezpośrednio w MapAnalyst ze względu na brak możliwości automatowego generowania stosownych etykiet, których brak znacznie utrudnia interpretację wyników ${ }^{16}$. Nie wzięto pod uwagę również wektorów przemieszczeń i rotacji z powodu ich słabej czytelności w analizie materiałów niemalże całkowicie kartometrycznych.

Głównym narzędziem, jakim posłużono się w celu przeprowadzenia poniższych analiz, był pakiet ArcGIS, który składa się m.in. z programów ArcMap i ArcScene. W pierwszym z nich dokonano analizy

\footnotetext{
${ }^{15}$ B. Jenny, L. Hurni, Studying cartographic heritage, s. 402-411.

${ }^{16} \mathrm{M}$. Kuźma, The use of GIS Tools.
}

skali i odległości, a także uruchomiono model przepływu danych określający sumy błędów bezwzględnych odległości w poszczególnych punktach mapy. Następnie dokonano ich wizualizacji 3D z wykorzystaniem ArcScene.

Dodatkowo wykorzystano niekomercyjny program QGIS, który umożliwił stworzenie i uruchomienie narzędzia obliczającego skalę ogólną badanej mapy. Co więcej, stworzono z jego użyciem wszystkie ryciny prezentowane w niniejszym artykule. Oferuje on bowiem wygodne opcje symbolizacji warstw wektorowych, niekiedy bardziej efektywne niż w innych komercyjnych programach GIS.

\section{Wizualizacja wyników analizy kartometryczności mapy}

Analiza kartometryczności mapy została przeprowadzona na podstawie piętnastu regularnie rozmieszczonych punktów stabilnych (ryc. 2). W celu ich wyznaczenia mapa została umieszczona w układzie współrzędnych płaskich prostokątnych PL-1992 (EPSG: 2180) za pomoca transformacji wielomianem pierwszego stopnia, przy użyciu piętnastu punktów kontrolnych. Transformacja ta jest podawana jako jedna z najbardziej użytecznych podczas badania dokładności map, ponieważ nie generuje dużych odkształceń i pozwala na uzyskanie wiarygodnych wyników, przesuwając, obracając i skalując osobno na osiach $\mathrm{X}$ i $\mathrm{Y}^{17}$. Jako materiał referencyjny wykorzystano warstwę punktową Państwowego Rejestru Nazw Geograficznych (PRNG) pobraną ze strony https://www.geoportal.gov.pl/dane/

\footnotetext{
${ }^{17}$ B. Jenny, A. Weber, L. Hurni, Visualizing the Planimetric Accuracy of Historical Maps with MapAnalyst, „Cartographica”, 42 (1), 2007, s. 89-94; P. Noszczyński, „Analiza kartometryczności historycznych źródeł kartograficznych w środowisku GIS przy wykorzystaniu danych archeologicznych z obszaru średniowiecznego palatium w Ingelheim am Rhein", praca magisterska, Uniwersytet Jagielloński, 2012 (https://unigis.sbg. ac.at/files/Mastertheses/Full/40123.pdf, dostęp: 14 października 2021); V. Baiocchi, K. Lelo, Georeferencing the Historical Maps of Rome Between the Seventeenth and Eighteenth Centuries, CIPA XX International Symposium, Turin 2005.
} 


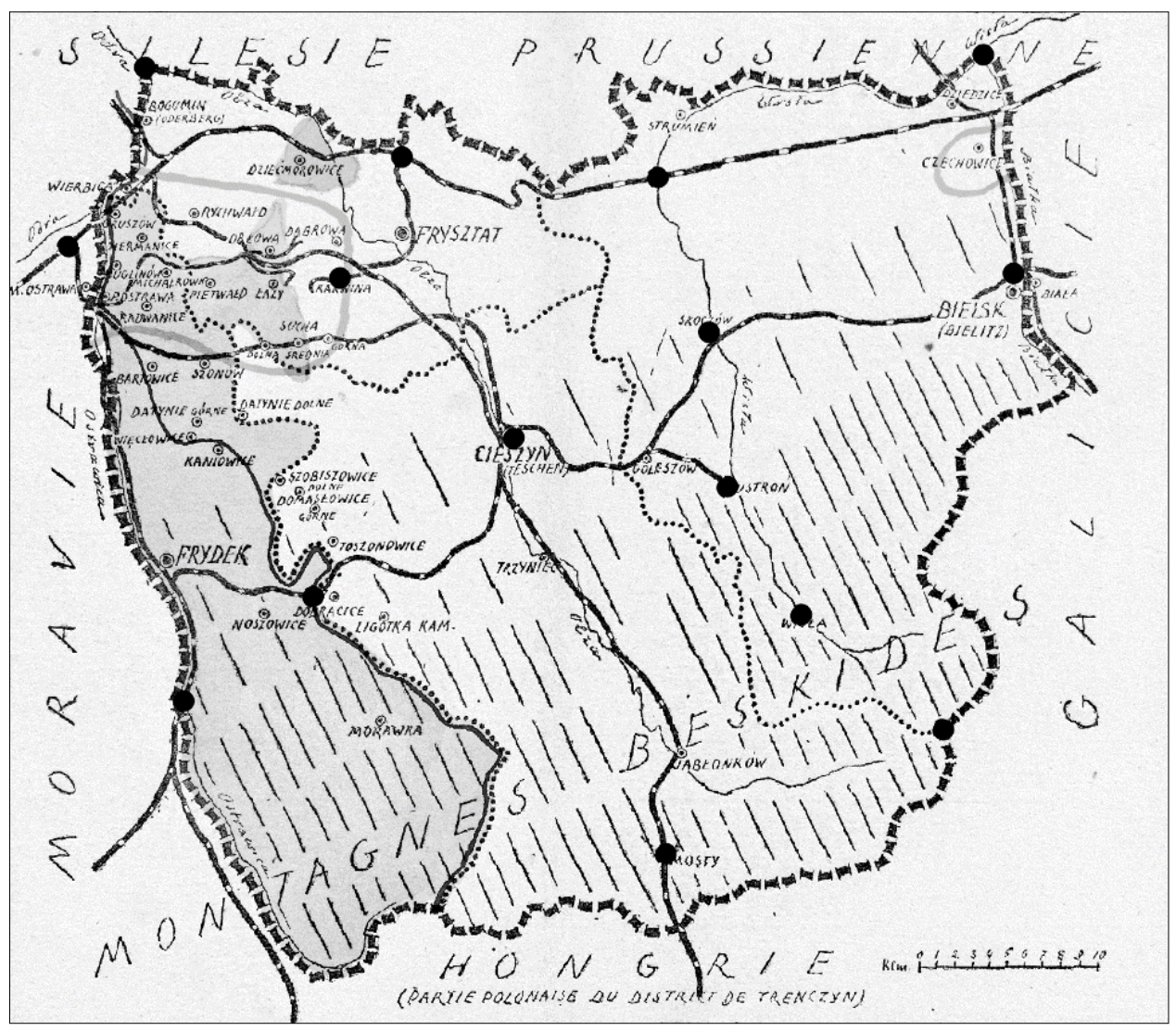

Ryc. 2. Piętnaście regularnie rozmieszczonych punktów stabilnych.

Żródto: oprac. własne

panstwowy-rejestr-nazw-geograficznych oraz warstwę OpenStreetMap (OSM). Dobór większej liczby punktów stabilnych okazał się być niemożliwy ze względu na nieprecyzyjne położenie miejscowości. Kierowano się zatem przede wszystkim biegiem rzek i skrzyżowaniami sieci kolejowych. Tak dobrane punkty same w sobie mogły generować błąd. Pierwiastek błędu średniokwadratowego (RMSE) dopasowania mapy do układu wyniósł $419 \mathrm{~m}$.

Do przeprowadzenia analizy skali niezbędne są pomiary dokonane na oryginalnej mapie. Aby stworzyć imitację mapy papierowej $\mathrm{w}$ oryginalnym rozmiarze, skonstruowano układ lokalny przy pomocy podziałki widniejącej na mapie. Podobne rozwiązanie zaproponował Piotr
Noszczyński ${ }^{18}$, jednak posiadał on oryginalne wymiary badanych planów. Twórca mapy nie zamieścił skali liczbowej, jednak większość map Księstwa Cieszyńskiego $z$ tego okresu posiada skalę 1:200 000 . Zakładając, że ten przypadek nie jest wyjątkiem, wykonano eksperyment polegający na umieszczeniu mapy w punkcie zerowym układu PL-1992 (EPSG: 2180), a następnie zmierzono długość jednego centymetra podziałki oraz dłuższego i krótszego boku mapy przy pomocy wektorowej warstwy liniowej. Pozyskane wymiary boków podzielono na odległość jednego centymetra podziałki i tak uzyskano wymiary arkusza mapy podane w centymetrach, które

${ }_{18}$ P. Noszczyński, „Analiza kartometryczności”. 
następnie przekonwertowano na metry. Wymiary te posłużyły jako współrzędne czterech narożników mapy, której nadano georeferencję, umieszczając lewy dolny róg w punkcie zerowym układu. Użyto, jak wyżej, transformacji wielomianem pierwszego stopnia i uzyskano RMSE równy w przybliżeniu $0,19 \mathrm{~mm}$. Wymiary ramki mapy wyniosły $31,43 \mathrm{~cm}$ szerokości i 25,99 cm wysokości. Według aplikacji MapAnalyst, wymiary te wyniosły odpowiednio $31,70 \mathrm{~cm}$ i $26,00 \mathrm{~cm}$. To świadczy o tym, że metoda imitacji arkusza papierowego jest bardzo dokładna.

\section{Analiza skali}

Podstawową analizą skali było wyznaczenie skali ogólnej opracowania. W tym celu wykorzystano samodzielnie napisany skrypt, który tworzy dwa zestawy macierzy odległości pomiędzy punktami stabilnymi mapy dawnej i mapy referencyjnej ${ }^{19}$. Tabela wynikowa (tab. 1) pokazuje skale lokalne mapy, których średnia arytmetyczna wynosi 1:225 568. Program MapAnalyst dokładniej wylicza skalę, ponieważ opiera się na obliczeniach wynikających z transformacji afinicznej, która również kompensuje odkształcenia spowodowane kurczeniem się papieru ${ }^{20}$. Raport wygenerowany w aplikacji przedstawia porównanie trzech metod transformacji i ich wpływ na oszacowanie skali mapy (ryc. 3). Oba wyniki nie różnią się znacząco, mimo skuteczniejszej metody wyznaczania skali w programie MapAnalyst.

Tabela 1. Fragment tabeli wynikowej algorytmu obliczającego skalę ogólną dawnej mapy.

\begin{tabular}{|c|c|c|c|c|}
\hline $\begin{array}{c}\text { ID mapy } \\
\text { referencyjnej }\end{array}$ & $\begin{array}{c}\text { ID mapy } \\
\text { dawnej }\end{array}$ & $\begin{array}{c}\text { Dystans mapy } \\
\text { referencyjnej [m] }\end{array}$ & $\begin{array}{c}\text { Dystans mapy } \\
\text { dawnej [m] }\end{array}$ & Skala lokalna \\
\hline 0 & 1 & 12797 & 0,06 & $1: 228910$ \\
\hline 0 & 2 & 51381 & 0,22 & $1: 233016$ \\
\hline 0 & 3 & 35822 & 0,16 & $1: 224707$ \\
\hline 0 & 4 & 60845 & 0,27 & $1: 224942$ \\
\hline 0 & 5 & 40729 & 0,18 & $1: 223470$ \\
\hline 0 & 6 & 49709 & 0,23 & $1: 220387$ \\
\hline 0 & 7 & 35379 & 0,16 & $1: 224050$ \\
\hline 0 & 8 & 23569 & 0,10 & $1: 230460$ \\
\hline 0 & 9 & 21027 & 0,09 & $1: 227010$ \\
\hline 0 & 10 & 29576 & 0,13 & $1: 228602$ \\
\hline
\end{tabular}

Źródło: oprac. własne

\begin{tabular}{|lllll|}
\hline Helmert (4 Parameters) & \multicolumn{2}{l|}{ Affine (5 Parameters) } & \multicolumn{2}{l|}{ Affine (6 Parameters) } \\
Scale: $1: 223000$ & Scale Hor.: & $1: 218700$ & Scale Hor.: & $1: 219000$ \\
Rotation: $\quad 1^{\circ}[\mathrm{ccw}]$ & Scale Vert.: $1: 229600$ & Scale Vert.: & $1: 230000$ \\
Std. Deviation: $\pm 476 \mathrm{~m}$ & Rotation: & $1^{\circ}[\mathrm{ccw}]$ & Rotation X: & $1^{\circ}[\mathrm{ccw}]$ \\
Mean Pos. Err.: $\pm 673 \mathrm{~m}$ & Std. Deviation: $\pm 249 \mathrm{~m}$ & Rotation Y: & $1^{\circ}[\mathrm{ccw}]$ \\
& Mean Pos. Err.: $\pm 352 \mathrm{~m}$ & Std. Deviation: $\pm 254 \mathrm{~m}$ \\
& & & Mean Pos. Err.: $\pm 359 \mathrm{~m}$ \\
\hline
\end{tabular}

Ryc. 3. Raport pochodzący z aplikacji MapAnalyst, prezentujący porównanie metod transformacji. Źródło: oprac. własne

\footnotetext{
${ }^{19}$ M. Kuźma, The use of GIS Tools.

${ }^{20}$ B. Jenny, L. Hurni, Studying cartographic heritage, s. 402-411.
} 


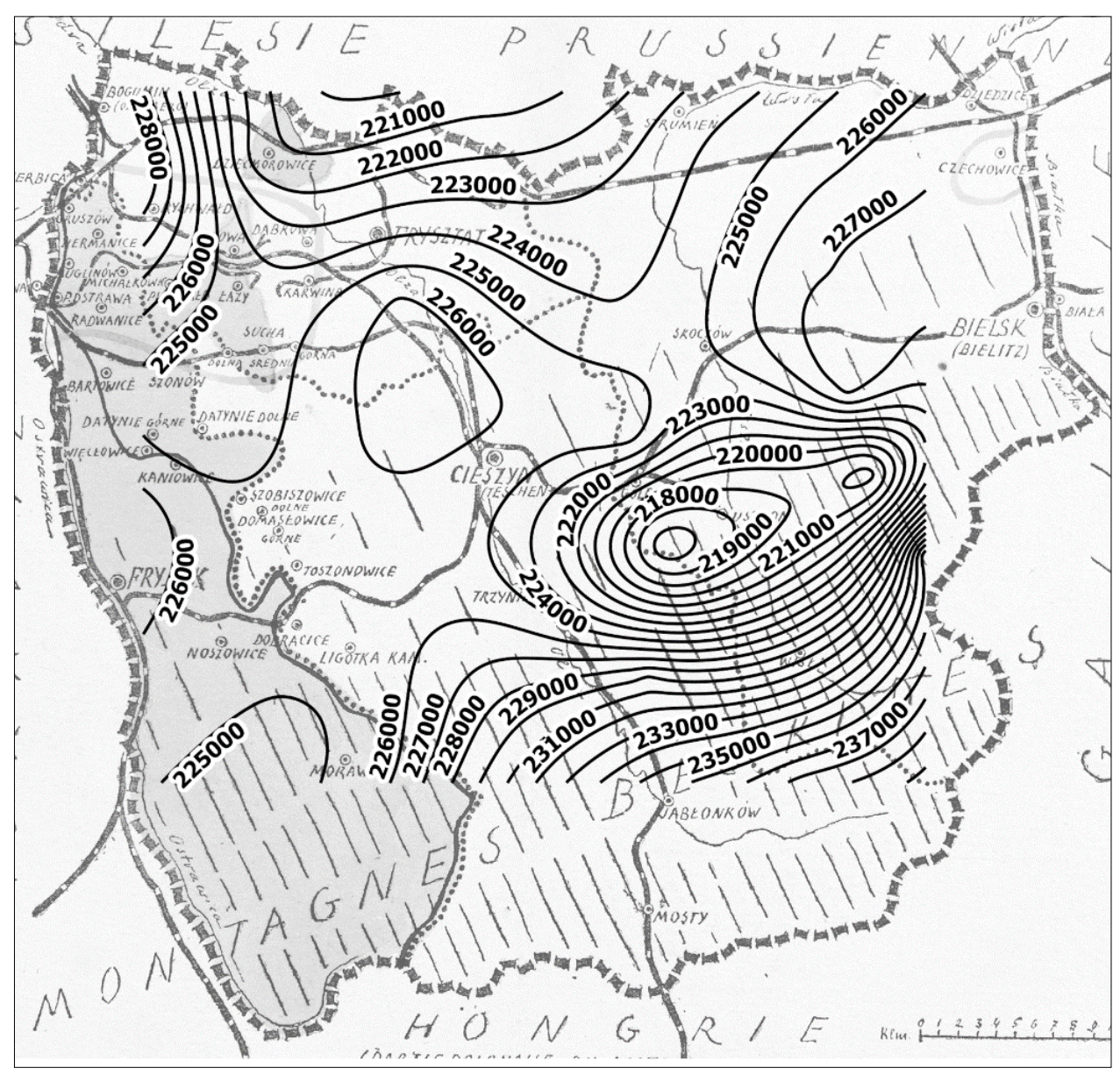

Ryc. 4. Izolinie zmienności skali o interwale równym 1000.

Źródło: oprac. własne

Aby zwizualizować zmienność skali na mapie, skonstruowano izolinie zmienności skali. Zdecydowano się na samodzielne utworzenie izolinii w programie ArcMap ze względu na większy wybór interpolacji i wyświetlania etykiet - program MapAnalyst pozbawia użytkownika tej funkcji ${ }^{21}$. Analiza polegała na utworzeniu siatki trójkątów dla punktów stabilnych mapy dawnej i mapy referencyjnej, a następnie obliczeniu dla każdego z boków skali lokalnej, czyli ilorazu długości boku mapy referencyjnej i mapy dawnej. Kolejnym krokiem było obliczenie średniej

${ }^{21}$ M. Kuźma, The use of GIS Tools, s. $152-161$. arytmetycznej wszystkich boków trójkąta i przypisanie jej centroidowi ${ }^{22}$. Finalnie wykonano Numeryczny Model Terenu (NMT), wykorzystując narzędzie interpolacji Topo to Raster, a następnie zamieniając go na izolinie narzędziem Contour. Interwał izolinii ustawiono na 1000. Problematyczne przy tej metodzie jest automatyczne nadawanie ID bokom trójkąta, co skutkuje brakiem identycznych

\footnotetext{
${ }^{22}$ K. Nieścioruk, Analiza i ocena XVIII-wiecznego planu Lublina jako przykład kompleksowych badań dawnych materiatów kartograficznych, „Polski Przegląd Kartograficzny", 39 (2), 2007, s. 146-158; E. Krzywicka-Blum, Nowa metoda analizy i prezentacji zmienności skali dawnych map dużych obszarów, „Polski Przegląd Kartograficzny”, 26 (2) ,1994, s. 75-84.
} 


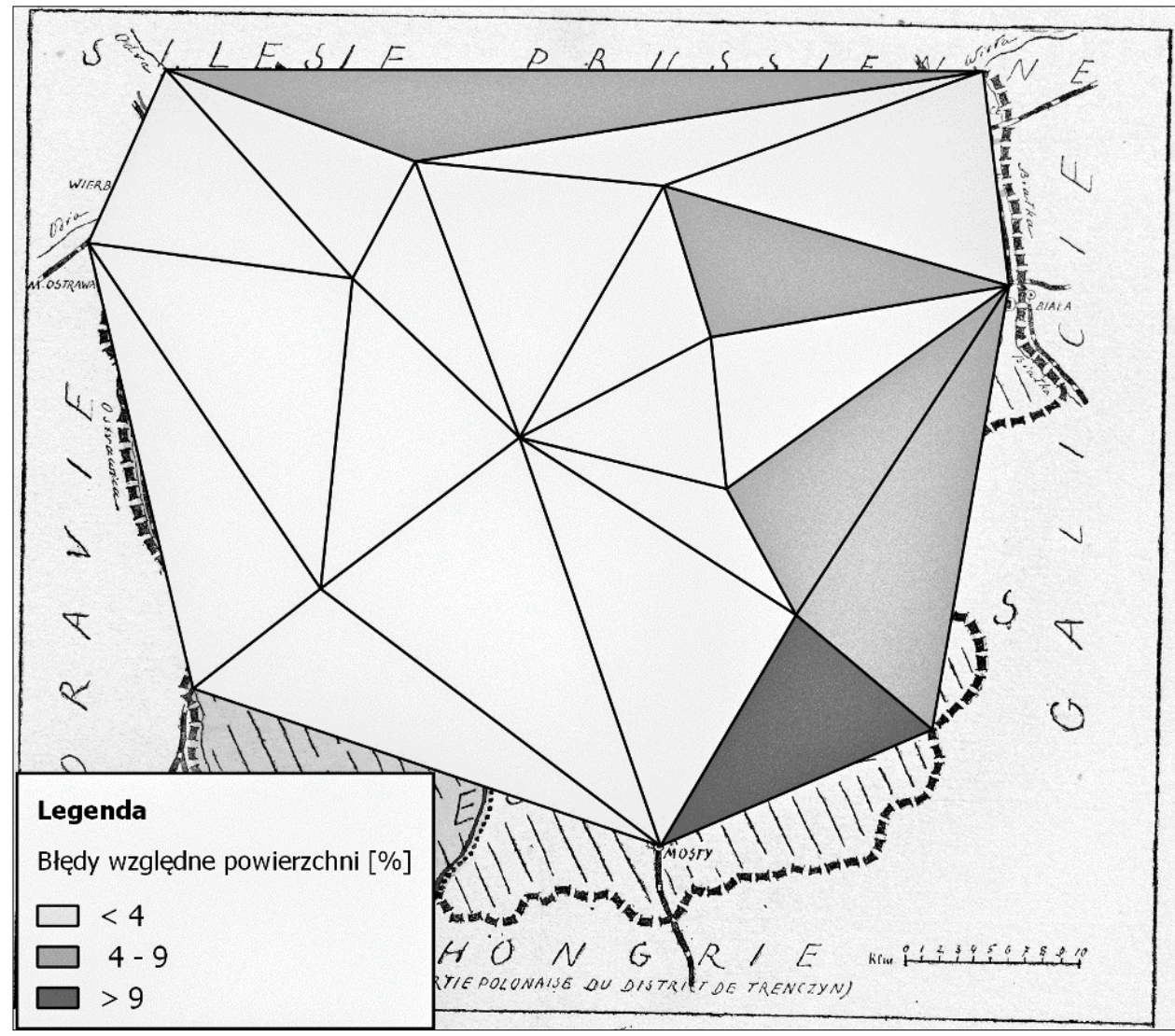

Ryc. 5. Btędy względne powierzchni wyrażone w procentach.

Źródto: oprac. własne

numerów dla dwóch zestawów siatek trójkątów oraz ich ręcznym poprawianiem ${ }^{23}$.

Naniesione na mapę izolinie pokazują największą zmienność skali w obszarze południowo-wschodnim oraz północno-zachodnim (ryc. 4).

\section{Analiza powierzchni}

Względne błędy powierzchni obliczono za pomocą dwóch zestawów siatek trójkątów skonstruowanych na punktach stabilnych skalibrowanej mapy dawnej i mapy referencyjnej. Po ujednoliceniu ID trójkątów oszacowano błąd względny

\footnotetext{
${ }^{23}$ M. Palczewski, ,Ocena kartometryczności planów miast Polski i krajów sąsiednich wydanych w okresie zimnej wojny", praca magisterska, UMCS, 2020 (https://apd.umcs.pl/diplomas/145718/?_s=1, dostęp: 14 października 2021).
}

wyrażony w procentach. Zrezygnowano z nadawania wagi poszczególnym trójkątom $^{24}$. Wyniki pogrupowano w trzy kategorie (ryc. 5). Największy błąd względny wyniósł 11,7 proc. i zlokalizowany został na północnym wschodzie mapy.

\section{Analiza odległości}

Analizę odległości wykonano za pomocą modelu przepływu danych uruchamianego w programie ArcMap, który wczytuje od użytkownika dwa zestawy punktów stabilnych i na ich podstawie wylicza sumę bezwzględnych błędów odległości, a następnie przypisuje je do każdego punktu

${ }^{24}$ K. Nieścioruk, Analiza iocena XVIII-wiecznego planu Lublina, s. 146-158. 


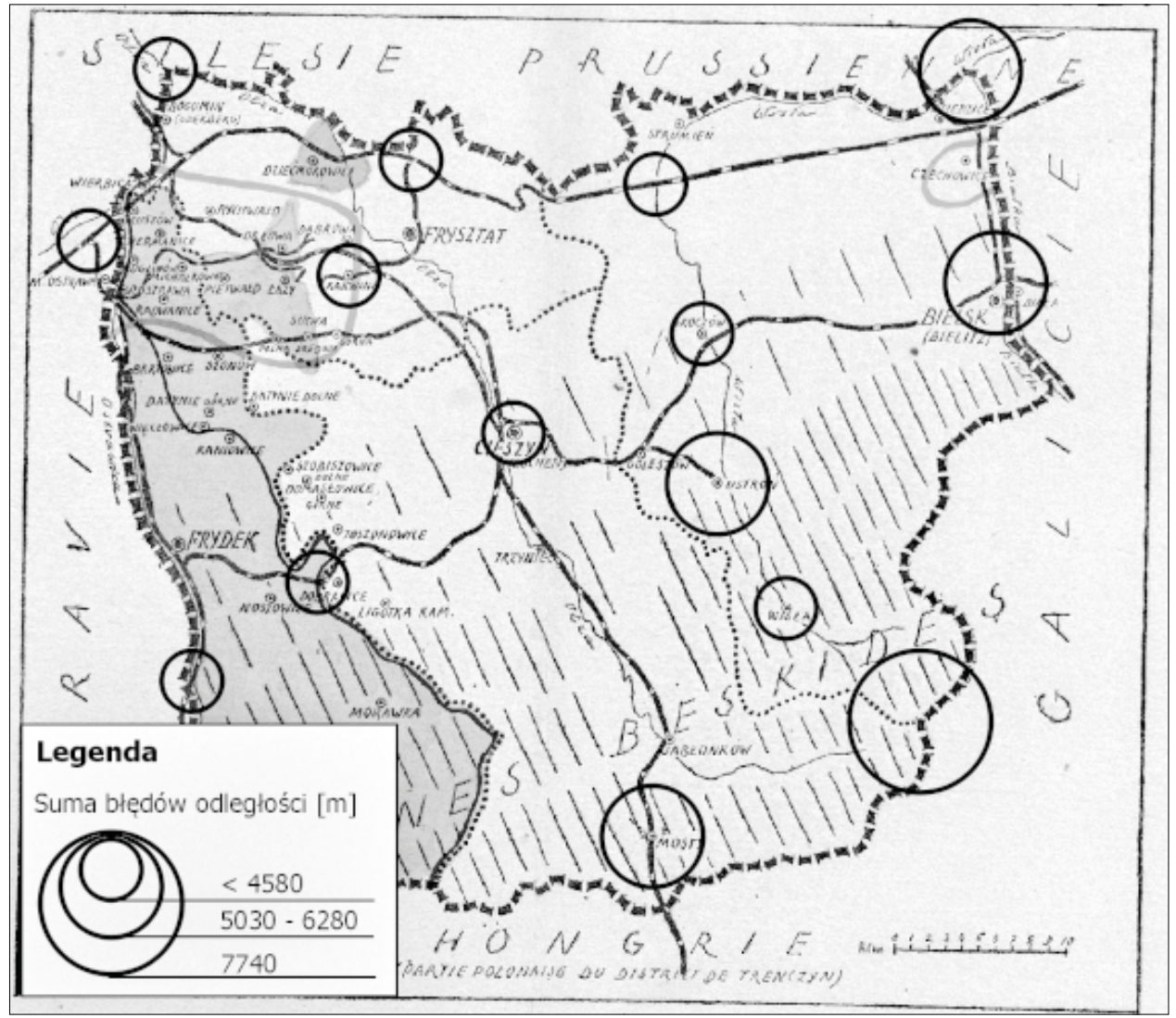

Ryc. 6. Sumy błędów bezwzględnych opracowane metodą okręgów dla każdego punktu stabilnego dawnej mapy. Źródto: oprac. własne

stabilnego mapy dawnej ${ }^{25}$. Graficzną prezentację wyników wykonano metodą okręgów proporcjonalnych do wartości sumy błędów bezwzględnych obliczoną w danym punkcie (ryc. 6) ${ }^{26}$. Symbole okręgów wykonano w programie QGIS ze względu na możliwość stylizowania warstwy za pomocą reguł. Największe sumy błędów bezwzględnych odnotowano w części wschodniej mapy.

Obliczone sumy bezwzględnych błędów odległości wykorzystano do wizualizacji 3D błędów odległości w programie ArcScene (ryc. 7). Ten sposób prezentacji błędów odległości ma na celu zwiększenie

${ }^{25}$ M. Palczewski, Ocena kartometryczności planów.

${ }^{26}$ K. Nieścioruk, Analiza i ocena XVIII-wiecznego planu Lublina, s. 146-158. percepcji przekazu poprzez przesadne ich uwypuklenie. Model 3D przypomina naniesioną na mapę rzeźbę terenu, ponieważ utworzony jest z NMT powstałego poprzez interpolację punktów stabilnych mapy dawnej. Jednak największe wypukłości mapy nie przedstawiają wyniosłości terenu, tylko miejsca, gdzie suma błędów jest największa. Dla zwiększenia czytelności wizualizacji stworzono płaszczyznę, która oddziela miejsca prawie całkowicie pozbawione błędu od obszarów o największych sumach błędów bezwzględnych.

Podczas tworzenia wizualizacji wzięto pod uwagę kilka metod interpolacji dostępnych w ArcMap, jednak zdecydowano się na wykorzystanie Inverse Distance Weighted (IDW). Ta metoda zakłada, że 


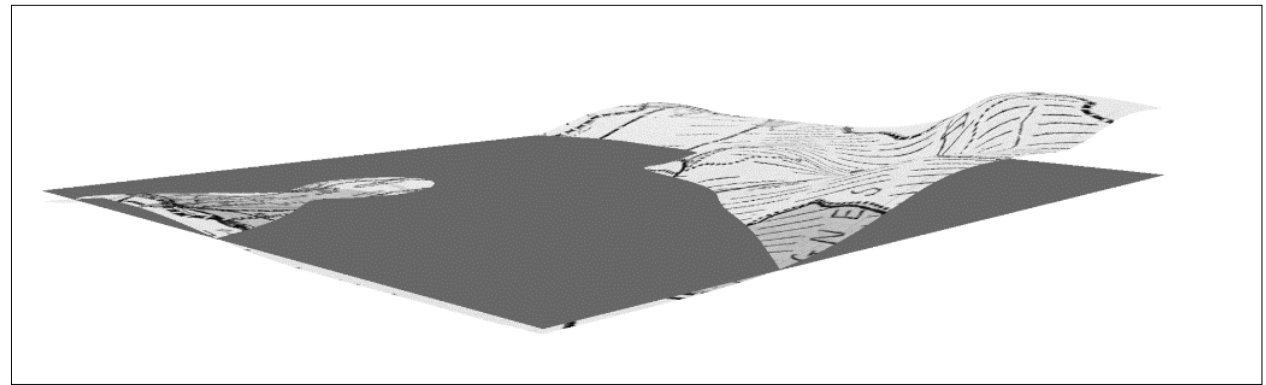

Ryc. 7. Wizualizacja 3D sumy bezwzględnych btędów odległości mapy (fragment animacji).

Źródto: oprac. własne

punkty położone bliżej prognozowanego miejsca mają większy wpływ na wynik, niż te bardziej oddalone. Dlatego każdy punkt na mapie otrzymuje wagę $\mathrm{w}$ postaci odwrotności jego odległości od prognozowanego miejsca. Prognozy te są potęgowane za pomocą dowolnej wartości - im większa wartość, tym większy wpływ odległości punktu na interpolację ${ }^{27}$.

Metoda IDW ma tę zaletę, że powierzchnia interpolowana nie przekracza wartości maksymalnej i minimalnej punktów próbkowania, co jest istotne dla tej wizualizacji. Ważne jest również to, że wyniki nie są uśredniane dla całej powierzchni, ale uzależnione są od wartości sąsiednich, co pozwala uzyskać dokładniejsze wyniki.

Ustawiając parametry narzędzia jako wartość Z, czyli wysokość, wskazano kolumnę przechowującą sumy błędów. Po ocenie kilku wyników z wykorzystaniem różnych potęg, zdecydowano się na wartość 1 , co oznacza, że wpływ odległości od punktu prognozowanego jest optymalny. Tak powstałe wartości NMT przypisano mapie dawnej. Ze względu na słabą widoczność błędów na mapie ustawiono współczynnik konwersji wartości wysokości z 1 na 1,5, dzięki czemu sztucznie wyeksponowano miejsca najmniej dokładne. Wizualizacja została udostępniona pod linkiem: https://youtu.be/3kppCuMtr5U. Na ukazanej animacji widoczna

\footnotetext{
${ }^{27}$ D. Watson, G. Philip, A Refinement of Inverse Distance Weighted Interpolation, „Geoprocessing,", 2, 1985, s. 315-327.
}

jest przewaga błędów występująca na południowo-wschodniej oraz północno-zachodniej części mapy.

\section{Siatka zniekształceń}

Najbardziej intuicyjną w interpretacji metodą przedstawienia niedoskonałości mapy jest siatka zniekształceń. Najszybszym sposobem jest wygenerowanie jej w aplikacji MapAnalyst. W procesie tworzenia siatki wykorzystywana jest metoda opracowana przez Dietera Beinekego. Polega ona na konstrukcji wektorów przemieszczenia poprzez transformację punktów stabilnych mapy referencyjnej do mapy badanej, a następnie obliczeniu pionowych i poziomych różnic w obu zestawach punktów stabilnych. Różnice te są wykorzystywane do wyznaczenia parametrów interpolacji wielokwadratowej ${ }^{28}$. Następnie tworzona jest regularna siatka w układzie współrzędnych mapy odniesienia, która ulega transformacji afinicznej do układu mapy badanej. Finalnie, siatka jest zniekształcana przy użyciu wcześniej wspomnianej interpolacji wielokwadratowej ${ }^{29}$.

\footnotetext{
${ }^{28}$ B. Jenny, L. Hurni, Studying cartographic heritage, s. 402-411; D. Beineke, Verfahren zur Genauigkeitsanalyse für Altkarten, „Schriftenreihe des Studiengang Geodäsie und Geoinformation der Universität der Bundeswehr München", 71, 2001.

${ }^{29}$ B. Jenny, A. Weber, L. Hurni, Visualizing the Planimetric Accuracy, s. 8994; R. Nicolai, Analysing MapAnalyst and its Application to Portolan Charts, ,e-Perimetron”, 13 (3), 2018, s. 121-140; S. Perthus, J. Faehndrich, Visualizing the Map-Making Process. Studying 19th Century Holy Land Cartography with MapAnalyst, „e-Perimetron”, 8 (2), 2013, s. 60-84.
} 


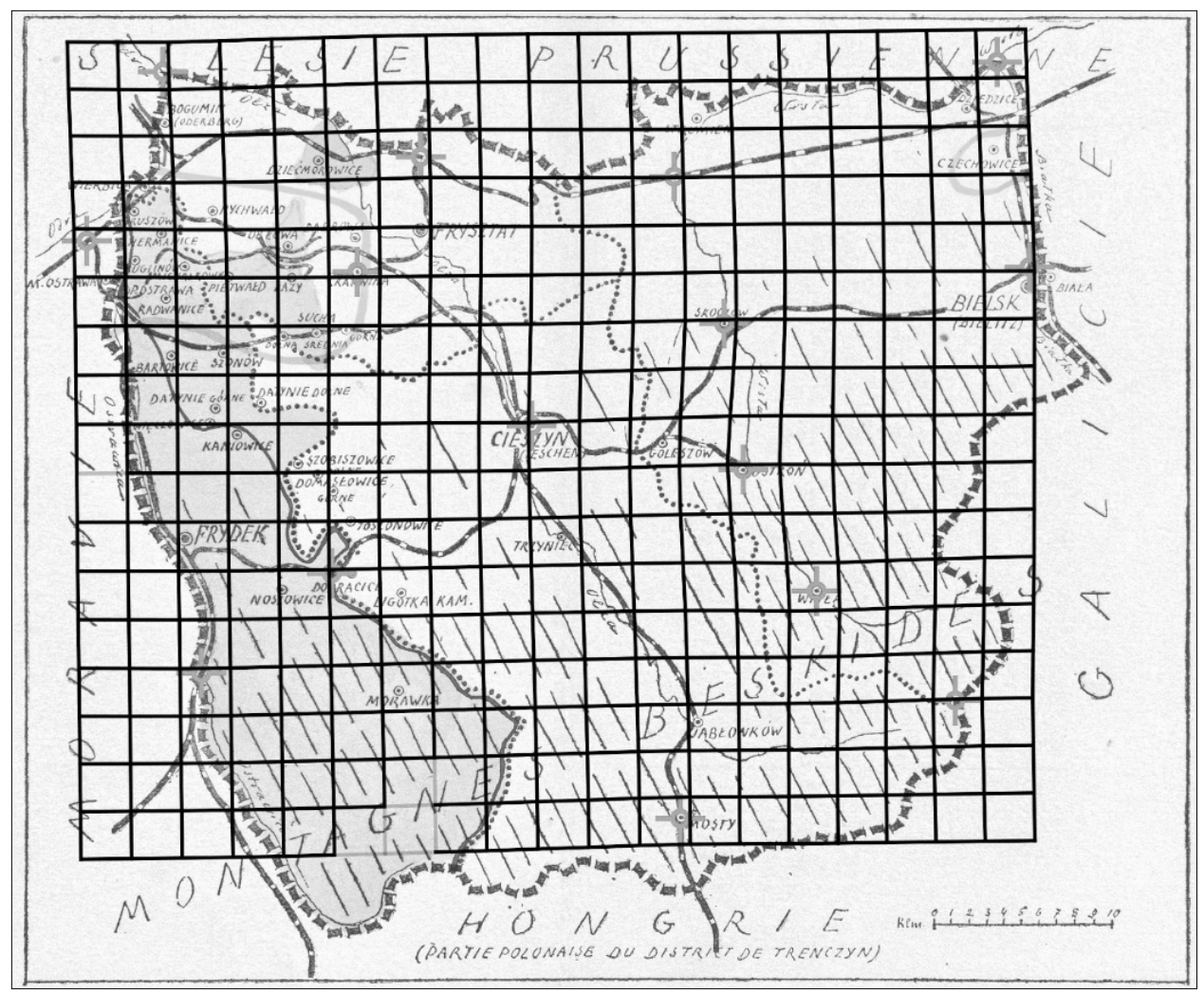

Ryc. 8. Siatka znieksztatceń bez zastosowanego wzmocnienia.

Żródto: oprac. własne

Dla omawianej mapy zastosowano transformację afiniczną 5-parametrową ze względu na najmniejszy, spośród trzech dostępnych transformacji afinicznych, błąd dopasowania oraz odchylenie standardowe (ryc. 5). Następnie, wygenerowano siatkę o rozmiarze jednego oczka równym $3000 \mathrm{~m}$ oraz zasięgu prostokątnym, jednak występujące na mapie deformacje były tak nieliczne, że odkształcenia siatki nie były widoczne (ryc. 8). Dlatego zdecydowano się na zastosowanie czterokrotnego wzmocnienia zniekształceń siatki, co pozwoliło na zlokalizowanie największych niedoskonałości mapy (ryc. 9). Widoczna w dolnej części mapy przezroczystość miejscowa siatki oznacza, że na tym obszarze występuje niepewność wyniku. W tym przypadku powodem jest brak pobliskiego punktu stabilnego, który mógłby posłużyć do wyznaczenia kolejnego parametru interpolacji. Siatka została najbardziej zniekształcona na południowym wschodzie oraz nieznacznie na północnym zachodzie.

\section{Wnioski}

W artykule dokonano przeglądu wybranych metod wizualizacji wyników oceny kartometryczności map pod kątem możliwości ich zautomatyzowania. Badanie wiarygodności map pod względem dokładności geometrycznej wykonano na przykładzie mapy wybranej z zasobu pozostałego po konferencji pokojowej kończącej pierwszą wojnę światową. Po rozwiązaniu typowych problemów związanych z badaniem kartometryczności dawnych map dokonano wizualizacji otrzymanych wyników. Do tego celu wykorzystano formy prezentacji, oferowane przez twórców 


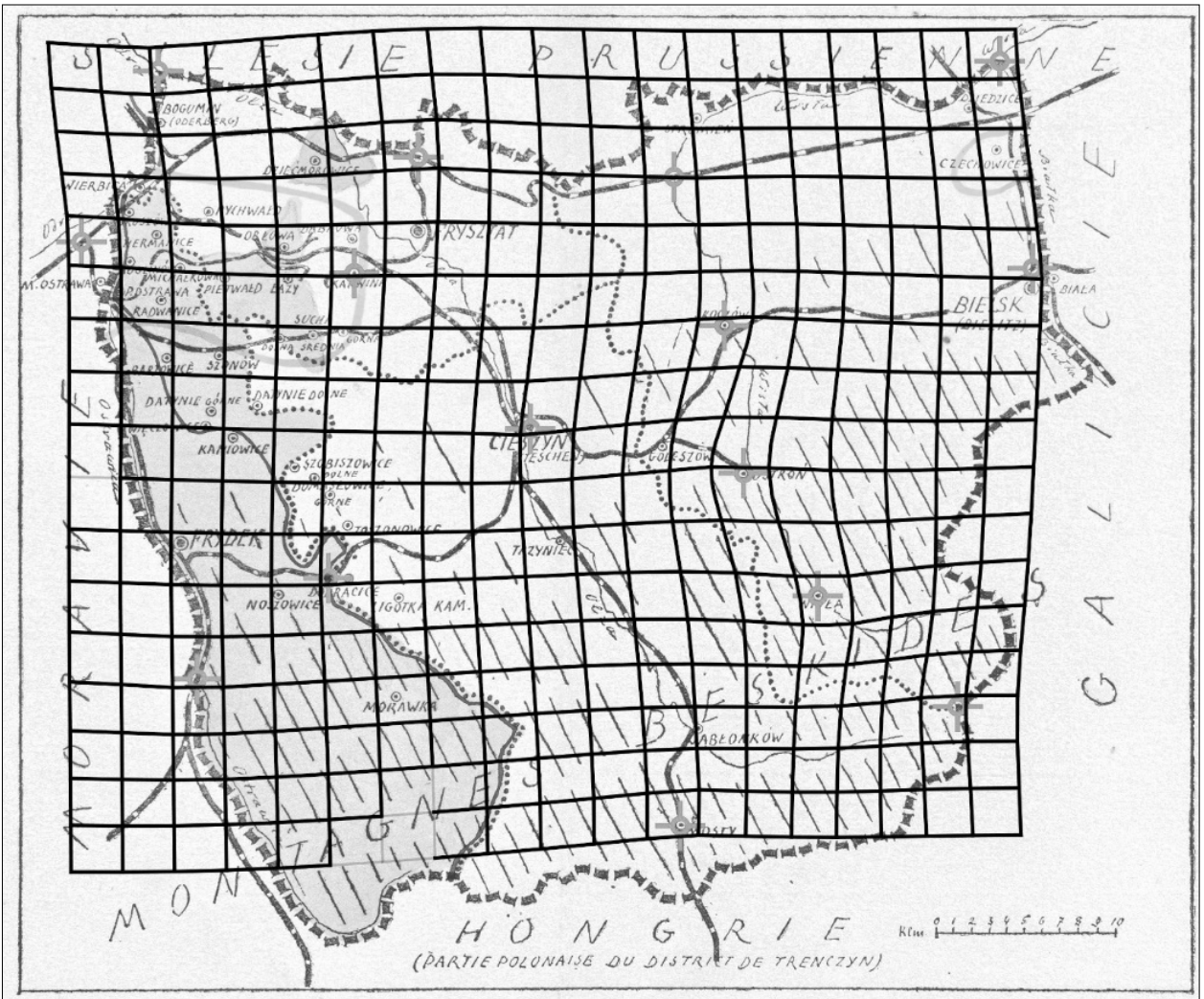

Ryc. 9. Siatka zniekształceń po zastosowaniu czterokrotnego wzmocnienia.

Źródto: oprac. własne

aplikacji MapAnalyst, QGIS oraz ArcMap i ArcScene z pakietu ArcGIS.

Otrzymane obrazy oceniono przede wszystkim pod kątem możliwości interpretacyjnych, tj. wyobrażenia sobie na ich podstawie zasięgu i stopnia deformacji powierzchni i odległości na mapie przez odbiorców niekorzystających na co dzień z kartograficznych metod prezentacji. Według Autorki sugestywność niektórych przedstawień wyraźnie ułatwia interpretację wyników, zwłaszcza w przypadku map podobnych do wybranej do testowania, czyli o niewielkim stopniu deformacji. $\mathrm{Z}$ powodu niewielkich zniekształceń, w niektórych formach przedstawienia błędów, jak siatka zniekształceń lub wizualizacja 3D sumy błędów odległości, należało zastosować sztucznie generowane wzmocnienie, by uwypuklić niedokładności mapy. Pomimo to, właśnie te dwa sposoby prezentacji, siatka zniekształceń lub wizualizacja 3D, wydają się najbardziej sugestywne i przemawiające do wyobraźni osób na co dzień niestosujących kartograficznych metod prezentacji. Pozostałe metody, zwłaszcza metoda trójkątów, są trudne w percepcji i interpretacji. Osiągnięte wyniki powinny jednak zostać poddane szerszym badaniom fokusowym, aby móc obiektywnie wskazać, która z tych metod prezentacji jest najbardziej czytelna dla większej grupy odbiorców. Wnioski zostaną opublikowane w późniejszych artykułach. 


\section{Podziękowanie}

Autorka dziękuje za udostępnienie źródeł kartograficznych dr hab. Beacie Konopskiej, prof. UMCS, kierownikowi projektu „Kształtowanie granic niepodległej Polski w świetle dokumentów kartograficznych", finansowanego w ramach programu MNiSW pod nazwą „Szlakami

\section{Bibliografia}

Baiocchi V., Lelo K., Georeferencing the Historical Maps of Rome Between the Seventeenth and Eighteenth Centuries, CIPA XX International Symposium, Turin 2005.

Beineke D., Verfahren zur Genauigkeitsanalyse für Altkarten, „Schriftenreihe des Studiengang Geodäsie und Geoinformation der Universität der Bundeswehr München”, 71, 2001.

Blakemore M.J., Harley J.B., Concepts in the history of cartography. Are view and perspective, „Cartographica", 17, 1980, s. 1-120.

Borowicz D., Dawne mapy przedmiotem manipulacji i narzędziem propagandy, „Z Dziejów Kartografii”, 21, 2017, s. 183-202.

Jenny B., Hurni L., Studying cartographic heritage. Analysis and visualization of geometric distortions, „Computers \& Graphics”, 35 (2), 2011, s. 402-411.

Jenny B., Weber A., Hurni L., Visualizing the Planimetric Accuracy of Historical Maps with MapAnalyst, „Cartographica”, 42 (1), 2007, s. 89-94.

Konopska B., Funkcje map przemystu Polski w atlasach wydanych w okresie PRL a sposób prezentacji danych, w: $Z$ dziejów przemystu po 1945 roku. Wroctawskie Spotkania z Historia Gospodarcza - Spotkanie VII, red. E. Kościk, R. Klementowski, Wrocław 2012, s. 21-32.

Konopska B., Wptyw aparatu wtadzy w latach 1944 1989 na polskie publikacje kartograficzne do użytku powszechnego, Warszawa 2012.

Konopska B., The Cartographic Materials Auxiliary in the Determination of the Borders of Poland during the Paris Peace Conference (1919-1920) in the Light of Archival Records, „Polish Cartographical Review”, 48 (2), 2016, s. 67-75.

Konopska B., Barwiński M., Przegląd odnalezionych źódet kartograficznych i tekstowych. Część pierwsza-Mapy Polski, 2019 (https://doi.org/10.13140/ RG.2.2.17544.55041).

Konopska B., Barwiński M., Przeglad odnalezionych źródet kartograficznych i tekstowych. Część czwartaGranica zachodnia i pótnocna, 2021 (https://doi. org/10.13140/RG.2.2.12728.47366).
Polski Niepodległej” w latach 2018-2023, nr projektu 01SPN17003218.

Szczególne podziękowania autorka formułuje pod adresem dr hab. Marka Barwińskiego, prof. UŁ za możliwość skorzystania z opisów merytorycznych map, poddanych badaniu kartometryczności.

Konopska B., Barwiński M., Przeglad odnalezionych źródet kartograficznych i tekstowych. Część trzeciaMapy Ślaska Cieszyńskiego, Orawy i Spisza, 2021 (https://doi.org/10.13140/RG.2.2.33442.76485).

Krzywicka-Blum E., Nowa metoda analizy i prezentacji zmienności skali dawnych map dużych obszarów, „Polski Przegląd Kartograficzny”, 26 (2), 1994, s. 75-84.

Kuźma M., The use of GIS Tools in the Automation of Examining the Cartometry of Old Maps, „Polish Cartographical Review”, 52 (4), 2020, s. 152-161.

Monmonier M., How to Lie with Maps, Chicago 1996.

Monnet J., The Symbolism of Place. A Geography of Relationships between Space, Power and Identity, „Cybergeo. European Journal of Geography. Political, Cultural and Cognitive Geography”, 562, 2011 (http://cybergeo.revues.org/24747, dostęp: 14 października 2021).

Nicolai R., Analysing MapAnalyst and its Application to Portolan Charts, „e-Perimetron”, 13 (3), 2018, s. 121-140.

Nieścioruk K., Analiza i ocena XVIII-wiecznego planu Lublina jako przyktad kompleksowych badań dawnych materiatów kartograficznych, „Polski Przegląd Kartograficzny”, 39 (2), 2007, s. 146-158.

Noszczyński P., „Analiza kartometryczności historycznych źródeł kartograficznych w środowisku GIS przy wykorzystaniu danych archeologicznych z obszaru średniowiecznego palatium w Ingelheim am Rhein”, praca magisterska, Uniwersytet Jagielloński, 2012 (https://unigis.sbg.ac.at/files/Mastertheses/ Full/40123.pdf, dostęp: 14 października 2021).

Palczewski M., „Ocena kartometryczności planów miast Polski i krajów sasiednich wydanych w okresie zimnej wojny", praca magisterska, UMCS, 2020 (https://apd.umcs.pl/diplomas/145718/?_s=1, dostęp: 14 października 2021).

Perthus S., Faehndrich J., Visualizing the Map-Making Process. Studying 19th Century Holy Land Cartography with MapAnalyst, „e-Perimetron”, 8 (2), 2013, s. 60-84.

Przybytek D., Kartograficzna wizja odradzającej się Polski w latach 1916-1921 i zmiana jej granic po 
1945 roku, „Z Dziejów Kartografii”, 23, 2020, s. $121-136$.

Szaniawska L., Obraz granic państwowych Polski w latach 1945-1958 na mapach towarzyszacych bilateralnym umowom państwowym, „Z Dziejów Kartografii", 23, 2020, s. 137-162.
Watson D., Philip G., A Refinement of Inverse Distance Weighted Interpolation, „Geoprocessing”, 2, 1985, s. 315-327.

Wood D., The Power of Maps, New York 1992.

\section{Review of methods of visualising the reliability of old maps in terms of geometric accuracy on the example of the map of Cieszyn Silesia}

\section{Summary}

This paper reviews selected methods for visualising the results of map cartometricity testing in terms of their potential for automation. The study of map reliability in terms of geometric accuracy was performed on the example of a map selected from the stock remaining after the peace conference ending World War I. The map of Le Duche de Cieszyn (Teschen) Silesie was chosen due to its high popularity; its copies can be found in archival collections preserved after the Paris conference and in individual legacies. There are many indications that it was the base for the preparation of other maps, held in manuscript form, and notes on various copies prove its use when the fate of this region was at stake.

The results obtained were visualised after solving the typical problems related to the study of cartometricity of ancient maps. For this purpose, the forms of presentation offered by the developers of MapAnalyst, QGIS, and ArcMap and ArcScene applications from the ArcGIS package were used.

The obtained images were evaluated primarily in terms of interpretative possibilities, i.e. imagining on their basis the map deformations (surface and distance) by recipients who do not use cartographic presentation methods daily. It seems that two of the analysed presentation methods, i.e. distortion grid and 3D visualisation of the sum of distance errors, appeal most to the imagination of those users. Other methods, especially the triangle method, are more difficult to perceive and interpret.

Maria Kuźma - geoinformatyk, doktorantka Szkoły Doktorskiej Nauk Społecznych Uniwersytetu Marii Curie-Skłodowskiej w Lublinie. Jej zainteresowania dotyczą kartografii i geografii historycznej. W zakresie tych zainteresowań zajmuje się badaniem kartometryczności dawnych map, używając i opracowując nowoczesne narzędzia GIS służące do automatyzacji procesów w badaniach kartograficznych

(m4ria.kuzma@gmail.com)

Maria Kuźma - GIS Specialist, PhD student at PhD School of Social Sciences at Maria Curie-Skłodowska University in Lublin. Her interests concern cartography and historical geography. Within the scope of these interests, she deals with research on cartometricity of old maps, using and creating modern GIS tools to automate processes in cartographic research (m4ria.kuzma@gmail.com) 